\title{
DETERIORATION OF DAMS IN CENTRAL YAKUTIA AS A SIGN OF GLOBAL WARMING
}

\author{
Syromyatnikov I. I. ${ }^{1}$, Gotovtsev S. P. ${ }^{1}$, Loskin M. I. ${ }^{2}$ \\ ${ }^{1}$ Melnikov Permafrost Institute SB RAS, Yakutsk, syromyatnikov@mpi.ysn.ru \\ ${ }^{2}$ GBU Uprmeliovodhoz, Republic of Sakha (Yakutia) Ministry of Agriculture \\ and Food Policy, Yakutsk,melio_delo@mail.ru
}

Central Yakutia is characterized by a lack of sufficient water supply for agricultural, industrial and household needs due to its climatic and environmental conditions. To cope the problem, a number of earthfill dams and dikes have been constructed since the 1950s to control water levels in local streams.

In recent years, many of the dams show signs of deterioration and damage associated with global warming. Dam degradation is thus becoming a serious concern for economic development in the regions with widespread permafrost. In addition to climate change effects, the dams are subject to anthropogenic pressure from increased water and heat loads from reservoirs. Representative examples are failures of the Siri Hollogos and Uhun-Ebe impoundment dams in 2014 and 2015.

Inspections of small earthen dams in the Lena-Amga watershed have found enhanced frozen ground activity, including thermokarst, thaw settlement, active layer slides and thaw-flow slides, along the shorelines of virtually all the reservoirs. The highest levels of risk are associated with abutments and outlet works.

We studied the temperature and moisture regime of the Kuogaly dam located in Churapcha District, Central Yakutia. Borehole drilling showed that the dam is founded on ice-rich permafrost. The dam embankment consists of loess-like silts with ice contents of 20-25\%. The tops of ice wedges were found by drilling to occur at depths of 1.5-2.0 $\mathrm{m}$ from the Kuokhara Creek bed. In vertical extent, the ice wedges are 6 to $8 \mathrm{~m}$ thick.

Thermal observations in the boreholes showed that temperature at the zero annual amplitude depth is about $-0.8^{\circ} \mathrm{C}$. This temperature is too high to provide adequate safety of the dam.

It is known that when dams are founded on ice-rich permafrost, structural problems are caused by thawing of ground ice $[1,2,3]$. This is confirmed by our investigations conducted at the Kuogaly dam. The results suggest that the cause for annual deformation of the fore apron is foundation subsidence due to melting of wedge ice.

Thus, in a warming climate, it is critically important to investigate the condition of dams and other water resources projects built on ice-rich permafrost.

\section{References}

1. Zhang, R.V. 1997. Features of deformations of small embankment dams and spillways on permafrost. Kriosfera Zemli (4): 66-71.

2. Zhang, R.V. 2000. Design, Construction, Operation and Maintenance of Small Dams in Permafrost Areas (on the Example of Yakutia). Yakutsk: Melnikov Permafrost Institute Press, $160 \mathrm{pp}$.

3. Zhang, R.V. 2002. Temperature Regime and Stability of Small Dams on Permafrost. Yakutsk: Melnikov Permafrost Institute Press, 208 pp. 


\title{
УХУДШЕНИЕ СОСТОЯНИЯ \\ ГИДРОТЕХНИЧЕСКИХ СООРУЖЕНИЙ \\ ЦЕНТРАЛЬНОЙ ЯКУТИИ КАК ПРИЗНАК ГЛОБАЛЬНОГО ПОТЕПЛЕНИЯ КЛИМАТА
}

\author{
Сыромятников И. И. ${ }^{1}$, Готовиев С. П. ${ }^{1}$, Лоскин М. И. ${ }^{2}$ \\ ${ }^{1}$ Институт мерзлотоведения им. П. И. Мельникова СО РАН, г. Якутск, \\ syromyatnikov@mpi.ysn.ru; \\ ${ }^{2}$ ГБУ Упрмелиоводхоз МСХиПП РС(Я), г. Якутск, \\ melio_delo@mail.ru
}

По природно-климатическим условиям Центральная Якутия мало обеспечена достаточным количеством воды как питьевого, так и хозяйственно-технического назначения. Начиная с 50-х годов прошлого века, данную проблему здесь стали решать путем строительства земляных дамб и плотин для регулирования уровня воды в местных водотоках.

В последние годы, в связи с глобальным потеплением климата, наблюдается износ и повреждение большинства таких плотин. Исходя из этого, одной из проблем освоения районов широкого распространения мерзлых грунтов становится ухудшение состояния гидротехнических сооружений.

Кроме того, гидротехнические сооружения испытывают не только общеклиматический, но и техногенный прессинг, обусловленный дополнительными водно-тепловыми нагрузками от самого водохранилища. Показательными примерами этих явлений стали аварии, произошедшие на плотинах водохранилищ «Сири-Холлогос» и «Усун-Эбэ» в 2014 и 2015 гг.

В результате рекогносцировочных обследований, проведенных на низконапорных гидроузлах Лено-Амгинского междуречья, выявлено, что по берегам практически всех водохранилищ активизировались криогенные процессы, такие как термокарст, термоэрозионные просадки, оползни и сплывы грунтов. При этом особо опасными элементами гидроузлов являются зоны примыкания плотин к бортам долин рек и ручьев, а также водосбросные сооружения [1].

Изучение термовлажностного режима плотины гидроузла «Куогалы» Чурапчинского улуса РС(Я) проводилось методом бурения скважин. Эти работы показали, что плотина построена на отложениях ледового комплекса. Тело плотины сложено лессовидными суглинками льдистостью $20-25 \%$. По данным бурения на глубине 1,5 - 2,0 м ниже основания плотины устанавливается верхняя граница подземных льдов. Вертикальная мощность повторно-жильных льдов составляет $6-8 \mathrm{~m}$.

Геотермические наблюдения в буровых скважинах показали, что температура на подошве слоя годовых теплооборотов имеет значение около $-0,8{ }^{\circ} \mathrm{C}$. Зафиксированная температура грунтов является весьма высокой для безопасной эксплуатации такого объекта. 
Известно, что при возведении плотин на льдистых основаниях причиной деформаций является оттаивание подземных льдов $[2,3]$. Это подтверждается нашими исследованиями, проведенными на гидроузле «Куогалы». Полученные результаты показывают, что причиной ежегодной деформации флютбета плотины является просадка грунтов его основания вследствие протаивания повторно-жильных льдов.

Таким образом, в условиях глобального потепления климата необходимо обратить самое серьезное внимание на изучение состояния гидротехнических сооружений в криолитозоне.

\section{Список литературы}

1. Чжан, Р. В. Проектирование, строительство и эксплуатаиия гидротехнических сооружений низкого напора в криолитозоне (на примере Якутии) / Р. В. Чжан. - Якутск : Изд-во ИМЗ СО РАН, 2000. - 160 с.

2. Чжан, Р. В. Особенности деформаций земляных плотин и водосбросных сооружений низкого напора в условиях вечной мерзлоты / Р. В. Чжан // Криосфера Земли. - 1997. - № 4. - С. 66-71.

3. Чжан, Р. В. Температурный режим и устойчивость низконапорных гидроузлов и грунтовых каналов в криолитозоне / Р. В. Чжсан. - Якутск : Изд-во ИМЗ CO PAH, 2002. -208 c. 